\title{
Három ország egy határtérsége ${ }^{1}$
}

\author{
LONCSÁK NOÉMI²
}

A Sik Endre és Surányi Ráchel által szerkesztett kötet három ország, Ukrajna, Szlovákia és Magyarország egymással érintkező, határ menti térségeit veszi górcső alá, kiemelve a két határvonal azonosságait, ellentéteit és alapvetően a különbözőségeit. A tanulmányok két nagyobb kutatás eredményeire ${ }^{3}$ támaszkodnak, melyek széleskörűen vizsgálják az eltérő módon változó határszakaszokat és az Európai Unióhoz füződő viszonyukat.

A kötet részletes elméleti felvezetője és a vizsgált térségek leírása, bemutatása részben értelmezési keretet biztosít az olvasó számára, részben az elemzés történelmi, földrajzi, gazdasági „beágyazását” szolgálja. A legterjedelmesebb második rész a határmentiség különböző dimenzióit ${ }^{4}$ tárja fel, melyeket a határon átnyúló kapcsolatok mentén jellemeznek az egyes tanulmányok szerzői. Ezt követi az identitás tárgykörében a határmentiség és a kvázidiaszpóra, az ebben megjelenő tanulmányok már sokkal inkább a személyes, egyéni terekben zajló „határhelyzetekre" fektetik a hangsúlyt. Egyéni vélemények is megjelennek határmenti kulcsszereplőktől és vázlatot kapunk a határvidékről, mint az Európai Unió külső határáról. A kötet terjedelmes módszertani melléklete a hasonló kutatásokat tervezők számára lehet igen hasznos.

${ }^{1}$ Sik Endre - Surányi Ráchel (2015): Határhatások. Eötvös Lóránd Tudományegyetem Társadalomtudományi Kar és a Tárki Társadalomkutatási Intézet Zrt. közös kiadása, Budapest

http://www.tarki.hu/hu/research/euborderregions/2015_hatarhatas.pdf

${ }^{2}$ Debreceni Egyetem, Szociológia és Szociálpolitika Tanszék, szociológia MA hallgató

${ }^{3}$ Az egyik kutatás: Az ELTE kutatóegyetemi programja a TÁMOP-4.2.1/B-09/1/KMR-2010-0003 azonosító számú, „Európai Léptékkel a Tudásért, ELTE - A felsőoktatás minőségének javítása a kutatás-fejlesztés-innováció-oktatás fejlesztésén keresztül” című projekt keretében valósult meg az Európai Unió támogatásával, az Európai Szociális Alap társfinanszírozásával, a másik: http://www.euborderregions.eu/

${ }^{4}$ Az intézmények között az egyházat, az iskolákat, a gazdasági szereplőket, helyi médiát, a munkaerőpiac kapcsán a határ szerepét és a jövedelemszerző mozgásokat, illetve a határmenti hálózatok együttműködési formáit vizsgálják. 


\section{OLVASS FELESLEGESET!}

\section{Intézmények a határokon átnyúlva}

Az intézmények közül a határmentiség kérdésében általában kiemelt szerepet kap a vallás, a vallásgyakorlás, amely az összetartozás-tudaton túl identitásképző dimenzióként van jelen. A kötet erre vonatkozó tanulmányában vizsgálják, hogy hogyan járulhat hozzá a határon átnyúló kapcsolatok fenntartásához. Az egyház szerepe nem zárul le a hitélet igényeinek kielégítésénél. A hármashatár vidékén egyrészt mintegy állampótló feladatokat vesz magára, ellát olyan szolgáltatásokat, amelyeket az állam nem képes. Ilyen például a határokon átnyúló tudástranszfer hálózatának kiépítését, lehetőséget biztosítani az embereknek és fenntartani azokat a kapcsolódási pontokat akár a határ átlépésével is. Másrészt identitásformáló és őrző szerepe miatt a vallás a magyarságtudat egyik alapeleme. ${ }^{5}$

Mivel az iskolarendszerek kérdését fókuszcsoportokkal vizsgálták, kiemelve négy intézményt (Szlovákiában a Királyhelmeci Gimnázium (Gymnázium Královský Chlmec), Ukrajnában a Beregszászi Magyar Gimnázium és a Beregszászi 4. számú Kossuth Lajos Középiskola, valamint Magyarországon a Sátoraljaújhelyi Kossuth Lajos Gimnázium, Szakképző Iskola és Kollégium) a hármashatár térségében, emiatt az eredmények inkább helyzetfeltáró jellegűek. A határ zártságából és nyitottságából adódó lehetőségek alapvetően áthatják a fiatalok életét, képzési lehetőségeiket. A szlovák oktatási rendszer hasonló a magyarhoz, mindössze néhány ponton van eltérés, míg az ukrán struktúra nagyon bonyolult, amelyben a könnyebb átjárhatóságot a korrupció jelenti. A szlovák és az ukrán gimnáziumokban a tanulók célja elsősorban a más országban való boldogulás, emiatt az adott országuk államnyelvének, szabályainak elsajátítása nem jelent motiváló erőt számukra. A régió egészére jellemző a gazdasági, munkaerőpiaci kilátástalanság, amelyből adódóan a felsőoktatásban az országból kilépő tanulók többsége nem tér vissza. A diákok jövővel kapcsolatos tervei a határ jellege és az adott ország mentén különböznek, azonban közös bennük a nyugat felé történő elvágyódás. Összességében megállapítják, hogy a vizsgált országok nem nyitottak az együttmüködésre az oktatás színterén, amely a fennálló nehézségek miatt „veszélyeztetheti a régió jövőjét” (Sik - Szécsi 2015: 156). Az általam kiemelt eredményeken túl a fókuszcsoportos adatfelvételnek köszönhetően színesen, olvasmányosan mutatja be a fejezet az iskolák helyzetét a határokon. ${ }^{6}$

A következő tanulmány a gazdasági szereplők közti határon átnyúló kapcsolatok intézményes feltételeit veszi sorra, melyet a kihasználatlanság jellemez. A magyar-szlovák határon a feltételek már a 90-es években kiépülésre kerültek, melyet az EU-s tagság tovább erősített, azonban a szerző a határ két oldalán jellemző gaz-

\footnotetext{
${ }^{5}$ A vallásról és az identitásformálás kapcsolatáról az érdeklődők Gereben - Tomka (2001), S. Szabó Péter - Grünhut Zoltán (2010) és Tomka (2011) szerzőknél olvashatnak tovább a témában.

${ }^{6}$ A határmenti térség oktatásáról értekezik Reisinger (2008) és a témában tanulmánykötet jelent meg Kötél - Szarka (2009) szerkesztésében.
} 


\section{OLVASS FELESLEGESET!}

dasági elmaradottságot nevezi meg a kihasználatlanság egyik kiváltó okaként. Nem számottevőek ezen a határszakaszon az átívelő tulajdonosi kapcsolatok, a munkaerőmozgás elhanyagolható és egyirányú. Az ukrán-magyar viszonylatot a szlovák állapotokon felül tovább nehezíti a határ zártsága, különbségként leírásra kerül a kereskedőturizmus meghatározó jelenléte, a jövedéki termékek csempészetére irányulva, amely gyakorlat napjainkra is meghatározó megélhetési forrás a kárpátaljaiak számára, és ami fenntartja a határokon átnyúló gazdasági kapcsolatokat.

A politikai és önkormányzati együttműködésekről és ezek intézményi, illetve szakpolitikai dimenziójának bemutatásáról külön tanulmány készült, mely a földrajzi értelemben körülhatárolt eurorégiók leírása mentén tér ki a magyar-szlovákukrán határtérségre. A szerző úgy látja, hogy a határok erős korlátozó funkciót jelentenek a személyek és intézmények számára, amely egyik esetben az EU külső, illetve belső határa, tehát alapvető eltéréseket rejtenek, gyakorlatilag azonban a lokális térbe kényszerítik a politikai szereplőket, a határokon való átívelés helyett. Végső következtetése szerint nem múködőképes a határszakaszok egységes elemként való kezelése a politikai, önkormányzati színtéren, hanem ezek funkcionális differenciálására lenne szükség.

Az intézményesített média vonatkozásáról csak a magyar-ukrán határtérségre vonatkozóan található elemzés a kötetben, amely átfogó médiaelemzést használ, tartalom és képelemzéssel keresve a határ két oldalán fellelhető különbségeket a határon átnyúló kapcsolatok ábrázolásában. Alapvető különbség, hogy Kárpátalján több figyelmet fordítanak a két ország kapcsolatára, gyakrabban jelenik meg a médiumokban, sok esetben magukba foglalva a kisebbségekkel való szolidaritást és az összetartozást. Felhívja a szerző a figyelmet továbbá a hírek és a képek eltérő konnotációjára, melyben a magyar oldalon fellépő hírek több esetben manipulatívak, befolyásolni szeretnék a médiafogyasztókat míg az ukrán oldali magyar nyelvű nyomtatott és online sajtóra ez kevésbé volt jellemző.

\section{Munkaerőpiaci tényezők}

Két tanulmány foglalkozik a munkaerőpiac egyes jellemzőivel, kiemelten a migrációs potenciál kérdésével és a jövedelemszerző mozgásokkal. Az elérhetőség és a határhoz való közelség migrációra gyakorolt hatásában nem mutatható ki nagyobb különbség a két vizsgált határszakasz között, az ukrajnai határnál ugyanakkor fontos, hogy csak a kapcsolati tőke bírt növelő hatással. A két migrációs típus (rövid- és hosszútávú munkavállalás) esélyét mindkét térségben a korábbi külföldi munkavállalás és a vállalkozói tapasztalatok befolyásolták legerősebben.

A külföldi munka és a határon átnyúló vállalkozás a három érintett ország közül Magyarországon a legkevésbé elterjedt, míg Ukrajnából és Szlovákiából jellemző a határátlépés ezen célokból, elsősorban jövedelemszerzésből kifolyólag. A külföldi 


\section{OLVASS FELESLEGESET!}

jövedelemszerzés ezen országokban is, leginkább a szakképzett, fiatal férfiak körében a leginkább jellemző.

\section{Hálózatok a hármashatár szereplőivel}

A szervezeti hálózatok releváns irodalmainak áttekintése után Gerő és Micsinai (1. a kötetben 267-296) foglalkozik a hálózati jellemzőkkel a határokon átnyúló szervezetek kapcsolatával. Tanulmányukban klaszteranalízist és brokerage-modellt is használnak az egyes kapcsolatok feltárására, fontosabb eredményük, hogy a határon átnyúló kapcsolatokban a legnagyobb szerepe az állami szervezeteknek van, továbbá Magyarország a három fél közül a legaktívabb szereplő. Vizsgálták a szektoriális megoszlásokat is, azonban a szervezetek tevékenységi köre több információval szolgált. $^{7}$

\section{Határmentiség kérdés}

A kötet szerzői vizsgálják a határsávban élők véleményei alapján a határ közelségéből fakadó előnyöket és hátrányokat, illetve, hogy ezek az egyéni vélekedések milyen valós tapasztalatokon alapulnak. A határmentiség szerepére vonatkozóan kitérnek továbbá két, általuk fontosnak tartott szolgáltatóintézményre, az iskolákra és az egészségügyi intézményekre. A határ közelsége a legtöbb előnyt az ukrajnai magyarság számára jelent, szorosan utánuk következnek a Szlovákiában élők, a Magyarországon élőket pedig a szerzők szavaival élve „hidegen hagyja” a határ közelsége. Okként mindhárom országban vezet a vásárlás, a legtöbb előnyt pedig az Ukrajnában élők nevezik meg: családi kapcsolatok, munkalehetőség, előnyös anyagok beszerzése, értékesítése. Multinomális regressziós modelljük eredményeként megállapították, hogy a haszonelvűség befolyásolja leginkább a határ átjárhatóságának megítélését.

Koltai és Ligeti (l. a kötetben 316-331) tér ki a határ menti lokális identitás tárgykörére, a határ túloldalához kapcsolódó szubjektív kötődést vizsgálták. Tanulmányukban külön értelmezték a szubjektív és a viszonylagost kötődést, és választ kerestek arra, hogy miben és milyen okból kifolyólag mutatnak mást az egyes országokban élők viszonyulásai a határ másik oldalához. Elsősorban nem társadalmi és demográfiai különbségekkel tudták magyarázni eredményeiket, hanem leginkább a történelmi-kulturális eltérésekkel, olyanokkal, mint a nyelvtudás, az elégedettség, a bizalom és a kapcsolati hálók szerepe.

\footnotetext{
${ }^{7}$ A hálózatokról két alapvető munkát írt Barabási (2003) és Bartal (2006), amely segíti az olvasókat eligazodni a témában.
} 


\section{OLVASS FELESLEGESET!}

\section{Kvázidiaszpóra}

Négy tanulmányt foglal csokorba a következő nagyobb blokk, amelyek témájukban egységeseknek tekinthetőek, amennyiben mindegyik valamilyen formában az identitás egy-egy aspektusát emeli ki. A nemzethez kötődő identitás, az önazonosság az első ilyen dimenzió, fontos, hogy a nemzeti és etnikai hovatartozás sok esetben nem esik egybe a vizsgált térségben. A három országban eltérő tényezők befolyásolták a nemzetfelfogást, például eltérő anyagi helyzetű csoportok az egyes országokban eltérően nyilatkoznak nemzeti identitásukkal kapcsolatban. Külön kitérnek a szerzők az identitás vesztés és az identitás átörökítésének kérdésére is.

A magyarság értelmezésére vonatkozóan modellek keresésével foglalkozik Pakot és Sőrés (l. a kötetben 376-395). Megállapítják, hogy a szlovákiai és ukrajnai magyarság magyar identitásának definiálása más módon épül fel, Szlovákiában inkább a kultúrnemzet domináns, míg Ukrajnában a nyelvi azonosulás.

A kvázidiaszpóra fejezetbe az identitáskérdések mellett egy mélyinterjús kutatás is színesíti a képet, melyet Herendi (2015) végzett Beregszászon és Mezőváriban, a közösségi élet aktív szereplőivel. Megismerheti az olvasó általa az emberek vélekedését a határmenti kapcsolatokról, a magyar állampolgárságról, az Európai Unióról és a református vallás és a magyar identitás kapcsolatáról Sik - Szécsi és Németh tanulmányaiból (l. a kötetben 410-436).

\section{Összegzés helyett}

A bemutatott kötet tipográfiája, szövegképe, stílusa, szellős szerkezete könnyen olvashatóvá teszi az elsőre robosztusnak látszó könyvet. Könnyű tájékozódni benne, a témában nem, vagy kevésbé jártas olvasók számára is, ezt könnyítik a nagyobb és kisebb fejezeti egységek. A Sik és Surányi által összegyújtött tanulmányok betekintést engednek egy speciális földrajzi és társadalmi egység - a határ - legfontosabb dimenzióiba. Külön erőssége továbbá a kötetnek, hogy a szerzők írásai a maga komplexitásában is helytállnak, azonban megfelelő közeget és értelmezési keretet kap az olvasó, amennyiben áttanulmányozza a Határhatások teljes repertoárját.

\section{Irodalom}

Barabási Albert-László (2003): Behálózva. Magyar Könyvklub, Budapest

Bartal Anna Mária (2006): A hálózatelemzés gyakorlati lehetőségei és gyakorlati konzekvenciái a civil szervezetek vizsgálatában - egy ernyőszervezet esettanulmánya alapján. Kutatási zárójelentés, Budapest http://www.szulokalapitvany. tsoft.hu/digitalcity/servlet/PublishedFileServlet/AAABZNJI/A+hálózatelem- 


\section{OLVASS FELESLEGESET!}

zés+lehetőségei+és+gyakorlati+konzekvenciái+a+nonprofit+szervezetek+vizsgálatában.pdf

Gereben Ferenc - Tomka Miklós (2001): Vallásosság és nemzettudat. Vizsgálódások Erdélyben. Teleki László Alapítvány - Corvinus Kiadó, Budapest

Kötél Emőke - Szarka László (szerk.)(2009): Határhelyzetek II. Kultúra - Oktatás Nyelv - Politika. Balassi Intézet Márton Áron Szakkollégium, Budapest http://mek.oszk.hu/09400/09428/09428.pdf

Reisinger Adrienn (2008): Oktatási kapcsolatok a szlovák-magyar határtérségben. Tér és Társadalom, 22(3): 127-149. http://epa.oszk.hu/02200/02251/00032/ pdf/EPA02251_Ter_es_tarsadalom2375.pdf

S. Szabó Péter - Grünhut Zoltán (szerk.) (2010): Vallás, politika, identitás. Publikon Kiadó, Pécs

Tomka Miklós (2011): A vallás szerepe az interkulturális kommunikációban. Vallásföldrajz és a vallási kultúrák regionalitása. Uniworld Közhasznú Egyesület. http://www.phil-inst.hu/uniworld/kkk/rel/geogr/tomka_3.htm 